\title{
Molecular Characterization of RNA3 of CMV Infecting Tomato from Karnataka, India
}

\author{
Gurudevi, V. Navali*, S. Basavaraj, K.T. Rangaswamy and H.A. Prameela \\ Department of Plant Pathology, College of Agriculture, UAS, GKVK, Bangalore-65, \\ Karnataka, India \\ *Corresponding author
}

\begin{tabular}{l}
$\begin{array}{l}\text { Key w or d s } \\
\text { Tomato, CMV, } \\
\text { RNA3 }\end{array}$ \\
\hline Article Info \\
\hline $\begin{array}{l}\text { Accepted: } \\
\text { 07 April } 2018 \\
\text { Available Online: } \\
10 \text { May } 2018\end{array}$ \\
\hline
\end{tabular}

A B S T R A C T
Tomato (Solanum lycopersicum L.) is one of the most important vegetable crop belongs to family Solanaceae. The production quality of tomato affected by array of biotic and abiotic stresses. Of these, biotic factors especially viruses are major constraint in tomato production. Among viruses infecting tomato, Tomato leaf curl virus (ToLCV), Tomato spotted wilt virus (TSWV), Cucumber mosaic virus (CMV), Tomato mosaic virus (ToMV), and Tobacco mosaic virus (TMV) presently known to contribute consistently to yield losses of tomato crop. After ToLCV and TSWV, CMV is severely affecting the tomato and cause fern leaf or shoe string disease. CMV infecting different crops have been classified into two subgroups (I and II) based on biological and serological properties as well as on the basis of $\mathrm{CP}$ sequence homology. Thus, in order to characterize CMV infecting tomato in Karnataka, RNA3 genome was amplified and sequenced. The molecular and phylogenetic analysis of RNA3 genome sequence of CMV infecting tomato revealed that CMV infecting tomato from Karnataka belongs to Sero group I.

\section{Introduction}

Tomato (Solanum lycopersicum L.) is one of the most important vegetable crops belonging to family Solanaceae. It is popular for its high nutritive value, taste and versatile uses (Passam et al., 2007). The major growing areas of tomato in India are Andhra Pradesh, Orissa, Madhya Pradesh, Karnataka, West Bengal, Maharashtra, Gujarat and Bihar. The production quality of tomato affected by array of biotic and abiotic stresses. Of these, biotic factors especially viruses are major constraint in tomato production. Among viruses infecting tomato, Tomato spotted wilt virus (TSWV),
Cucumber mosaic virus (CMV), Tomato mosaic virus (ToMV), Tomato leaf curl virus (ToLCV) and Tobacco mosaic virus (TMV) presently known to contribute consistently to yield losses of tomato crop (Jones et al., 1991 and Massumi et al., 2009).

A typical symptom of CMV in tomato is the occurrence of 'fern leaf', a filiform deformation of the leaves, also referred to as "shoe-string'" syndrome (Lesley and Lesley, 1928; Edwardson and Corbett, 1962). Since last four decades, severe CMV outbreaks have been reported from Mediterranean region (Gallitelli et al., 1991; Jorda et al., 1992). 
CMV is the type member of the genus Cucumovirus belongs to the family Bromoviridae. Virus particles are isometric with a diameter of $29 \mathrm{~nm}$ and have a tripartite genome of positive-senses sRNA (Palukaitis et al., 1992). In total, the viral genome encodes five ORFs: RNA1 is about $3.3 \mathrm{~kb}$ in length and encodes the $111-\mathrm{kDa}$ protein $1 \mathrm{a}$; RNA2 (3 kb) encodes the $98-\mathrm{kDa}$ protein $2 \mathrm{a}$, as well as the multifunctional 13 to $15-\mathrm{kDa}$ protein $2 b$ which is expressed from $a$ subgenomic RNA named RNA 4A; RNA3 is $2.2 \mathrm{~kb}$ in length and encodes the $30-\mathrm{kDa}$ movement protein (MP) $3 \mathrm{a}$ and the $25-\mathrm{kDa}$ coat protein (CP) $3 \mathrm{~b}$ (Garcia and Palukaitis, 2008). In nature, $\mathrm{CMV}$ is transmitted by $>60$ aphid species in the non-persistent manner and mechanically as well (Chandankar et al., 2013). Based on biological, serological, molecular and physical properties CMV strains were classified into two subgroups, I and II. Subgroup I strains were further divided into subgroups IA and IB, based on nucleotide variation in the 5' non-coding region of RNA3 (Roossinck et al., 1999). It is evident that subgroups II and IA have a worldwide distribution, while subgroup IB is mainly present in Asia. Though the disease on tomato has been known for quite long period, the literature available on etiology fern leaf disease of tomato in Southern India is rather meagre or scanty.

\section{Materials and Methods}

\section{Experimental site}

In the present study, the experiments were carried out in insect proof glasshouse at Department of Plant Pathology, University of Agricultural Sciences, GKVK, Bengaluru.

\section{Raising healthy tomato seedlings}

Tomato seedlings were raised in pro-trays containing coir pith. After 20-25 days old seedlings were transplanted into pot mixture containing soil + sand + FYM. These pots were kept in insect proof cages. Then, 15-20 days old seedlings were used as test plants for various experiments.

\section{Maintenance of CMV culture}

Tomato plants showing symptoms viz., mosaic, mottling, twisting, leaf distortion and fern leaf like appearance were collected from naturally infected plants from the experimental fields at UAS, GKVK, Bengaluru. The infected tissue samples were macerated and mechanically inoculated at two leaf stages to healthy tomato plants $\mathrm{cv}$. ArkaVikas using $0.1 \mathrm{M}$ phosphate buffer. The inoculated plants were kept in insect proof cages for symptoms expression and used as a stock culture. The stock culture was continuously maintained in the glasshouse by inoculating to the healthy tomato plants at regular intervals by sap inoculation for various experiments.

\section{RNA extraction}

Total RNA was extracted from Healthy and CMV infected tomato plants (Plate 1) using Qiagen plant RNA extraction kit and subsequently used for RT-PCR detection of CMV. Leaf tissue (100-200 mg) was ground to a fine powder in liquid nitrogen in a pestle and mortar and placed in a sterile micro centrifuge tube. The ground tissue was mixed with $1 \mathrm{ml}$ of homogenizing buffer. After incubation at $65^{\circ} \mathrm{C}$ for $10-15 \mathrm{~min}$, two chloroform-isoamyl alcohol (24:1) extractions were performed. RNA was precipitated from the aqueous layer, overnight, at $4^{\circ} \mathrm{C}$ with an equal volume of $4 \mathrm{M}$ lithium chloride. The pellet obtained by centrifugation for $30 \mathrm{~min}$ was resuspended in $200 \mu \mathrm{l}$ of TE buffer containing $1 \%$ sodium dodecyl sulfate and incubated at $-20^{\circ} \mathrm{C}$ for $30 \mathrm{~min}$ with $100 \mu \mathrm{l}$ of $5 \mathrm{M} \mathrm{NaCl}$ and $300 \mu \mathrm{l}$ of ice-cold Iso-propanol. 
Following centrifugation for $10 \mathrm{~min}$ the pellet was washed with $70 \%$ ethanol, repelleted, dried and dissolved in DEPC water. Stored at $80^{\circ} \mathrm{C}$ until further use.

\section{Reverse transcription polymerase chain reaction}

RNA from healthy and CMV infected tomato samples was taken for reverse transcription along with positive control (CMV on cucumber) and negative control (distilled water). $20 \mu \mathrm{IRT}$ mixture was prepared by adding the following ingredients into the PCR tube. 5X RT buffer (Supplied with the enzyme) $4 \mu \mathrm{l}, 25 \mathrm{mM} \mathrm{MgCl} 21.0 \mu \mathrm{l}, 10.0$ mMdNTP mixture 2.0 $\mu$, Reverse Primer (10 $\mathrm{mM}) 2.0 \mu \mathrm{l}, M u L v$ Reverse Transcriptase $0.5 \mu \mathrm{l}(100$ units $/ \mu \mathrm{l})$, Viral RNA 5.0 $\mu \mathrm{l}$, RNAase inhibitor $0.5 \mu \mathrm{l}$ and finally volume was made with sterile distilled water. Reaction mixture containing RNA $(5.0 \mu \mathrm{l})+$ Reverse primer CMV1R and 2R $(2.0 \mu \mathrm{l})$ was incubated at 74 ${ }^{\circ} \mathrm{C}$ for 5 minute and then quenched on Ice. Ingredients mixed to this mixture and reverse transcribed at $42{ }^{\circ} \mathrm{C}$ for 45 minute and then at $99{ }^{\circ} \mathrm{C}$ for 5 minute. The c-DNA thus obtained was used for performing PCR.

The c-DNA obtained was subject to PCR amplification using forward primer $(\mathrm{CMV} 1 \mathrm{~F}$ and $2 \mathrm{~F}$ ) are the overlapping primers known to amplify a $1200 \mathrm{bp}$ each, product from RNA extracted from CMV infected tomato plants which corresponded to the RNA3 of CMV. PCR amplifications were conducted in an thermo-cycler in $25 \mu \mathrm{l}$ reaction mixture that contained $2.0 \mu \mathrm{l}$ c-DNA, $0.2 \mu \mathrm{lTaq}$ DNA polymerase $(5 \mathrm{U} / \mu \mathrm{l}), 2.5 \mu \mathrm{l}$ of $10 \mathrm{X}$ PCR buffer (100 mMTris-HCl, pH 8.3, $500 \mathrm{mMKCl}, 15$ $\mathrm{mM} \mathrm{MgCl2}$ ), $0.5 \mu \mathrm{l}$ of $25 \mathrm{mM} \mathrm{MgCl} 2,2.0 \mu \mathrm{l}$ each primer $(10 \mu \mathrm{M}), 2.0 \mu \mathrm{ldNTPs} \operatorname{mix}(2.5$ $\mathrm{mM}$ each) and sterile water to make up the volume. The mixture was subjected to one cycle of initial Denaturation at $94{ }^{\circ} \mathrm{C}$ for $4 \mathrm{~min}$ followed by 30 cycles of Denaturation at 94
${ }^{\circ} \mathrm{C}$ for $30 \mathrm{~S}$, annealing at $53{ }^{\circ} \mathrm{C}$ for $30 \mathrm{~S}$, extension at $72{ }^{\circ} \mathrm{C}$ for $45 \mathrm{~S}$ and a final extension at $72{ }^{\circ} \mathrm{C}$ for $10 \mathrm{~min}$ (Shahanavaj et al., 2011). After the completion of the reaction, the products were kept at $4{ }^{\circ} \mathrm{C}$ prior to gel analysis.

\section{Gel electrophoresis and sequencing of PCR products}

Twenty microlitre aliquots from each PCR amplified product were analyzed by 1.0 per cent agarose gel electrophoresis at $60 \mathrm{~V}$ for 1 hr in 1X TBE buffer (Section 3.4.3). The gel was previously stained with ethidium bromide at $0.5 \mu \mathrm{g} / \mathrm{ml}$. The size of the amplification products was estimated from $1 \mathrm{~kb}$ DNA ladder (Gene Ruler TM, Cat. No. SM 0311, Fermentas, GMBH, Germany). PCR amplicons obtained by DNA components using specific overlapping primers were separately purified using QIA quick gel extraction kit (Cat. No. 28704; Qiagen, Germany) according to the instructions given by the manufacturer with some modifications. The DNA was eluted in $40-60 \mu$ of elution buffer depending on the initial intensity of the band in agarose gel. The eluted products were stored in $-20{ }^{\circ} \mathrm{C}$ until sent for sequencing bidirectionally with both reverse and forward primers to commercial sequencing service providers viz., Sci Genome sequencing Pvt. Ltd. Kocchi, Kerala.

\section{Sequence analysis of CMV RNA3}

The sequences obtained from both CMV forward and CMV reverse reactions were aligned and joined together to get full length sequence using 'nucleotide blast' at basic blast programmes and 'align two (or more) sequences' at specialized blast programmes freely assessing in 'Basic Local Alignment Search Tool (BLAST)' at the National Center for Biotechnology Information (http://www. ncbi.nlm.nih.gov/). 
Table.1 RNA3 sequences of various cucumber mosaic virus strains used for comparison

\begin{tabular}{|c|c|c|c|c|c|}
\hline Group & Accession no. & Strain & Origin & Host & $\%$ Identity \\
\hline \multirow[t]{6}{*}{$\mathbf{I A}$} & U66094 & Sny & USA & Tobacco & 92 \\
\hline & D10538 & Fny & USA & Tomato & 92 \\
\hline & U22821 & $\mathrm{Ny}$ & Australia & Cucumber & 92 \\
\hline & AB004781 & D8 & Japan & Radish & 89 \\
\hline & D28487 & FT & Japan & Tomato & 90 \\
\hline & AB004780 & KM & Japan & Melon & 91 \\
\hline \multirow[t]{4}{*}{ IB } & Y16926 & Tfn & Italy & Tomato & 98 \\
\hline & D28780 & NT9 & Taiwan & Cucumber & 97 \\
\hline & AB042294 & IA & Indonesia & Cucumber & 96 \\
\hline & KM272275 & $\mathrm{KO}$ & India & Chilli & 99 \\
\hline \multirow[t]{5}{*}{ II } & M21464 & Q & Australia & Cucumber & 80 \\
\hline & AF127976 & Ls & USA & Cucumber & 80 \\
\hline & L15336 & Trk7 & Hungary & Banana & 79 \\
\hline & L15358 & Banana & Hungary & Banana & 78 \\
\hline & $\mathrm{AB} 006813$ & $\mathrm{~m} 2$ & Japan & Musa sp. & 80 \\
\hline
\end{tabular}

Fig.1 Phylogenetic tree of nucleotide sequence of RNA3 of CMV-Tomato with the other strains of CMV Subgroup IA, IB and II. The tree was developed using neighbour-joining algorithm of

MEGA 6.06 version. Numbers at nodes indicate percentage boot strap confident scores (1,000 replications)

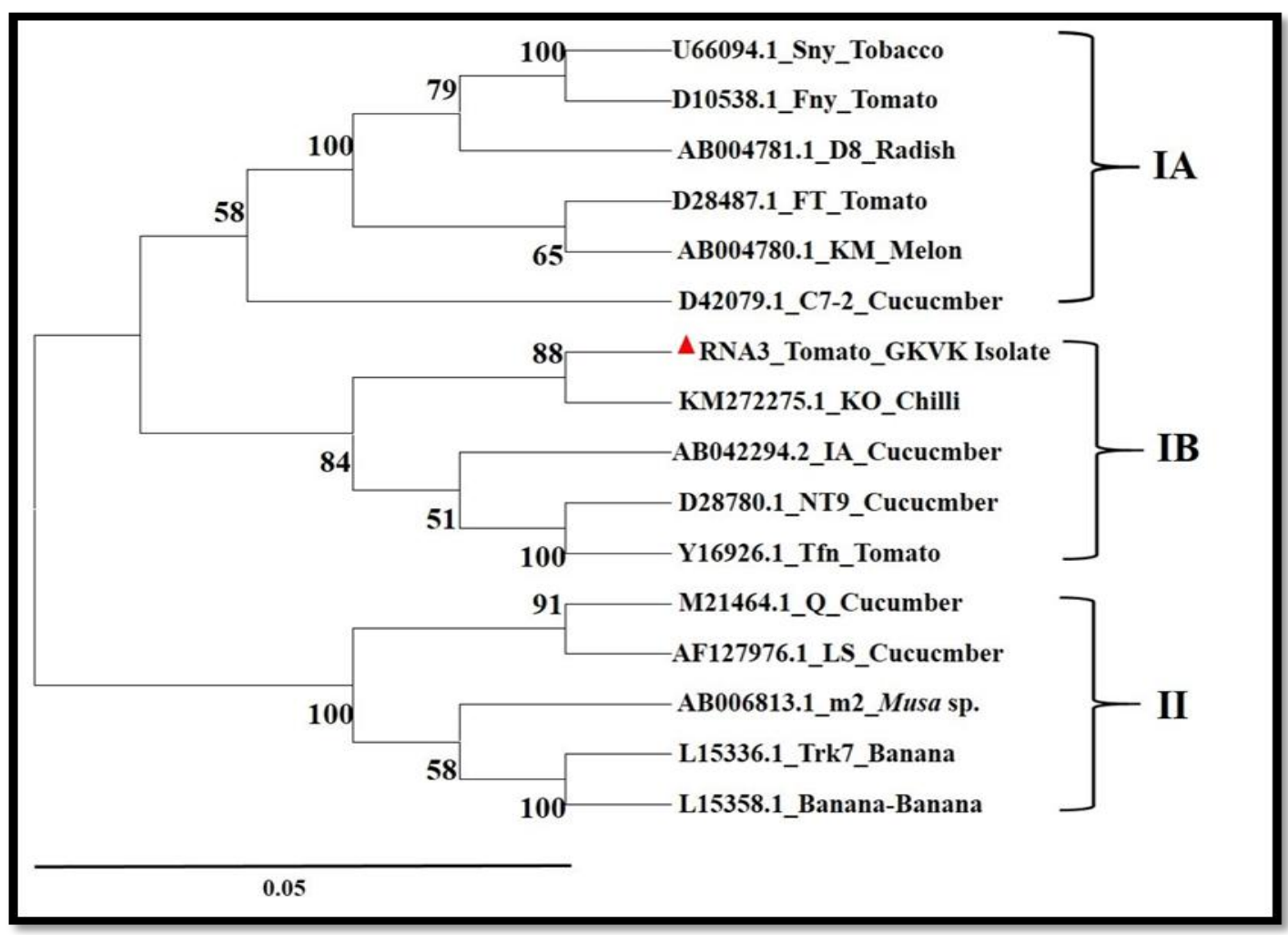


Plate.1 Healthy (A) and CMV infected (B) tomato plant showing typical shoe-string symptom

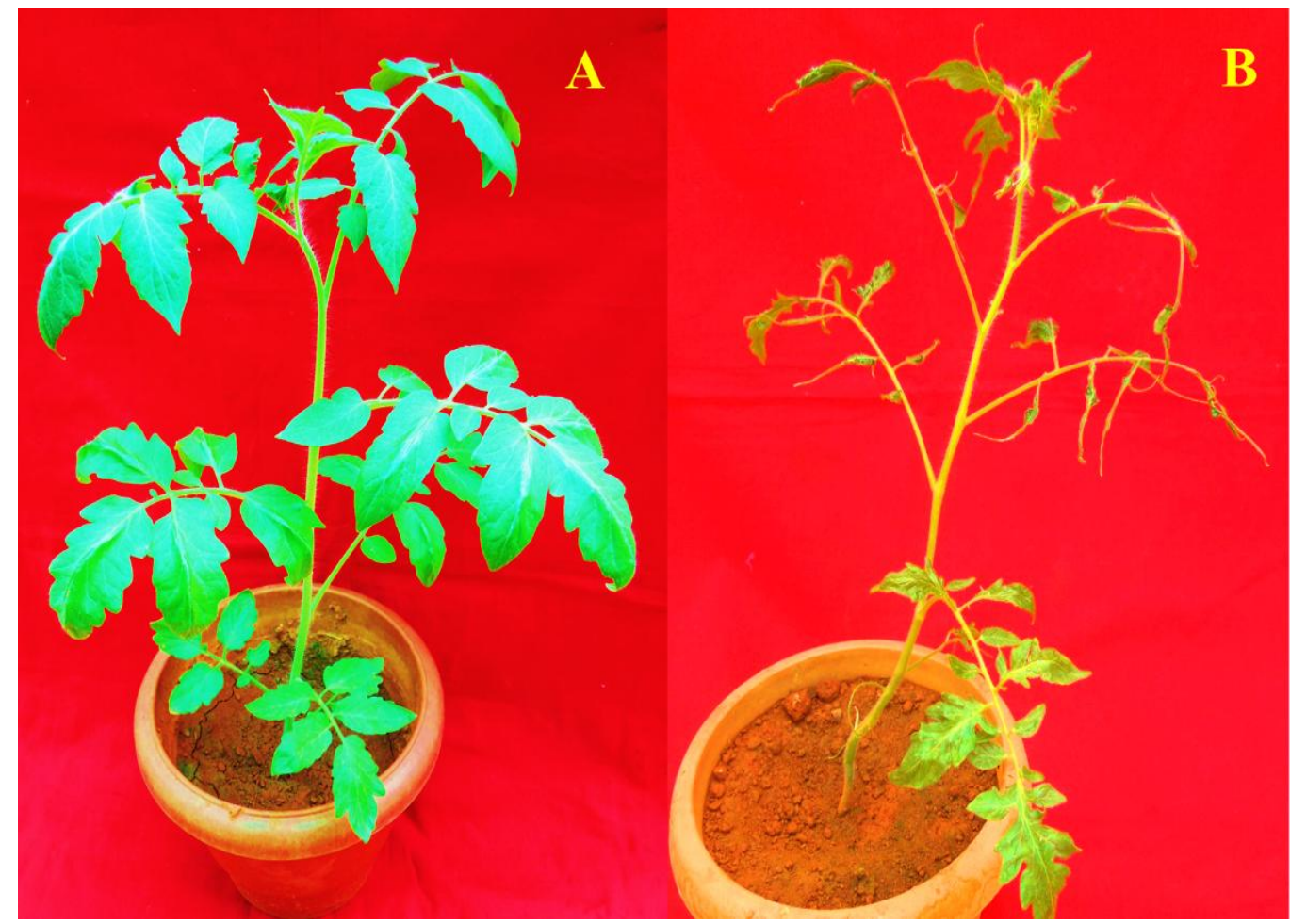

Plate.2 Gel picture showing amplification of RNA3 of CMV through RT-PCR

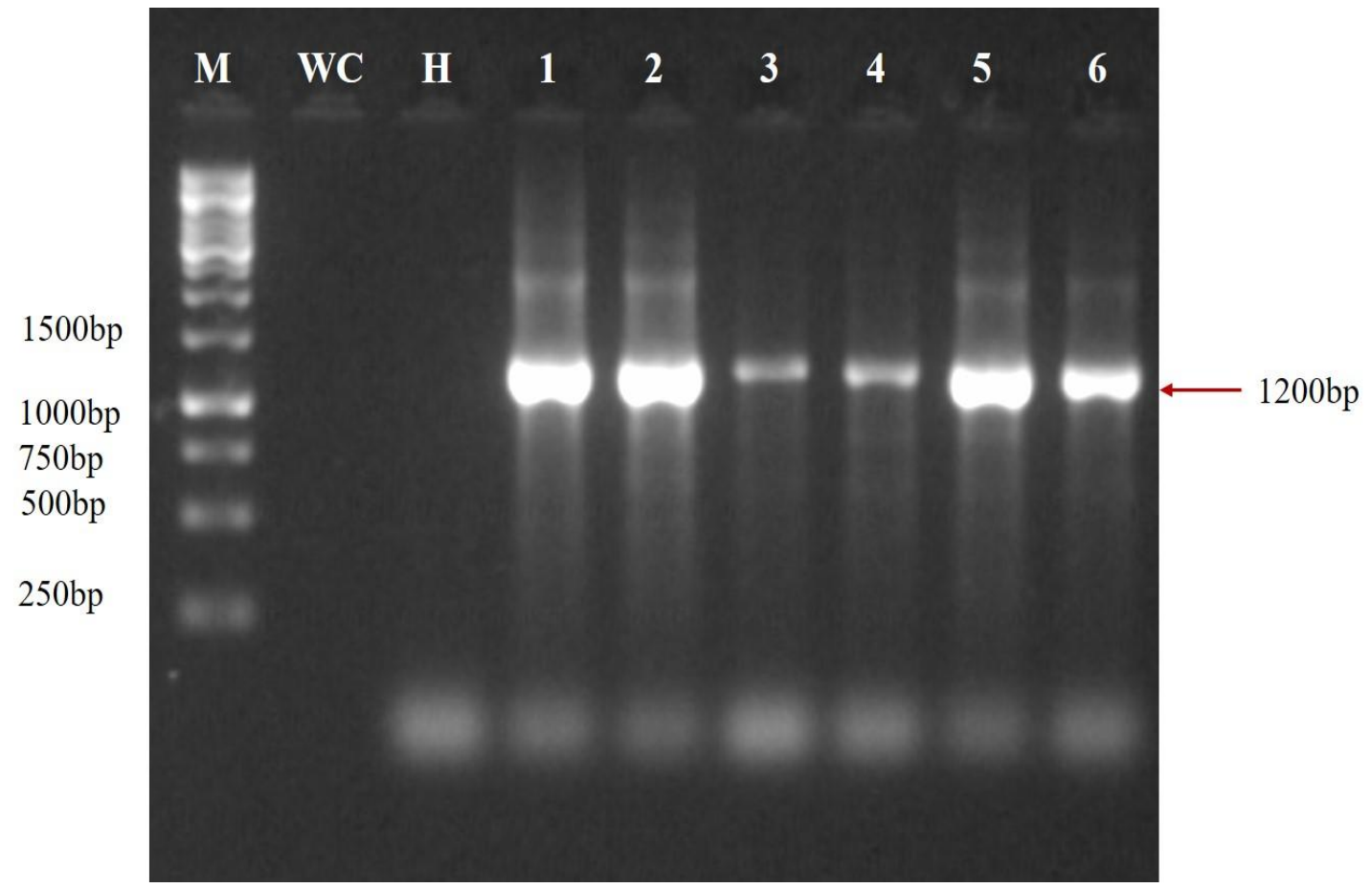

(M: 1Kb Marker, WC: Water control, H: Healthy tomato, 3\&4: +ve control, 5\&6: F1/R1 overlapping primer and 7\&8: F2/R2 overlapping primer) 
The complete full-length sequence was subjected to BLAST search. Sequences were compared with other respective viral sequences of the NCBI database using BLAST and multiple aligned using CLUSTALW2 multiple alignment tool (http://www.ebi.ac.uk/Tools/msa/clustalw2/).

The phylogenic neighbor-joining trees and evolutionary analysis were conducted using MEGA6.06 software package (Tamura et al., 2013). Robustness of trees was determined by bootstrap sampling of multiple sequence alignment with 1000 replications.

\section{Results and Discussion}

RT-PCR amplification of the RNA3 of tomato CMV using specific overlapping primers resulted in the amplification of $1200 \mathrm{bp}$ fragment from tomato and cucumber plants infected with CMV but no amplification was observed in healthy samples (Plate 2). The overlapping amplified products were eluted and sequenced. Sequence analysis of RNA3 revealed that RNA3 of CMV of tomato (GKVK isolate) showed highest nucleotide sequence identities with members of subgroup I especially, with KO-strain (99\%) (KM272275-Kolar) of CMV infecting hot and bell pepper. Further, sequence identities with members of subgroup IA and IB showed that CMV CP gene of tomato shared greatest identity with members of subgroup IB. Sequence similarities of nucleotide were in the range of $89-92 \%$ with subgroup IA isolates while it was 96-99\% with subgroup IB isolates. An identity 78-81 $\%$ was observed with subgroup II isolates.

Phylogram constructed using RNA3 of various strains of CMV (IA, IB and II) using MEGA6 version 6 revealed that CMV-GKVK isolate formed three distinct clusters comprising of CMV IA, IB and II subgroups. GKVK (Bengaluru) isolate of tomato belong subgroup IB (Figure 1). The CMV isolates used in phylogenetic analysis are listed in Table 1.

CMV has the broadest host range among the plant viruses and has been reported infecting tomato from various parts of the world. Sequence analysis of CMV isolate infecting tomato revealed a very high nucleic acid homology with the strains of CMV subgroup Ib. Such a high sequence homology of CMVTomato with the CMV subgroup Ib strains suggests a common origin of the virus. Also, these results are in contrast similar with the CMV infecting tomato in Lucknow also belongs to subgroup IB with a homology with of 96-97 per cent with other CMV strains of India (JF279606, GU111229) reported by Pratap et al., (2012).

Since tomato is one of the important vegetable crops, it becomes necessary to characterize the virus/es infecting the crop so that effective control measures can be developed to minimize the losses caused by viruses. Complete genome sequence of CMV plays an important role in designing new management practice by gene silencing.

\section{References}

Chandankar, V. D., Mondhe, M. K., Bhoyar, P. R., Ninawe, B. N. and Jadesha, G. (2013). Biophysical characterization, host range and transmission studies of Cucumber mosaic virus. The Bioscan, 8(2): 437-441.

Edwardson, J. R. and Corbett, M. K. (1962). A virus-like syndrome in tomato caused by a mutation. American J. Bot., 49: 571-575.

Gallitelli, D., Vovlas, C., Martelli, G., Montasser, M. S., Tousignant, M. E. and Kaper, J. M. (1991). Satellitemediated protection of tomato against Cucumber mosaic virus: II. Field test 
under natural epidemic conditions in Southern Italy. Pl. Dis., 75: 93-95.

Garcia, F. and Palukaitis, P. (2008). Cucumber mosaic virus. In "Desk Encyclopedia of Plant and Fungal Virology' pp. 171-176.

Jones, J. B., Jones, J. P., Stall, R. E. and Zitter, T. A. (1991). Compendium of Tomato Diseases. American Phytopathological Society Press, St. Paul, MN, USA, pp. 73.

Jorda, C., Alfaro, A., Aranda, M., Moriones, E. and Garcia, F. (1992). Epidemic of Cucumber mosaic virus plus satellite RNA in tomatoes in eastern Spain. $\mathrm{Pl}$. Dis., 76: 363-366.

Lesley, J. W. and Lesley, M. M. (1928). The "wiry" tomato: A recessive mutant form resembling a plant affected with mosaic disease. J. Hered., 8: 337-344.

Massumi, H., Shabanian, M., Hosseini, P. A., Heydarnejad, J. and Rahimian, $\mathrm{H}$. (2009). Incidence of viruses infecting tomato and their natural hosts in the Southeast and central regions of Iran. Pl. Dis. 93: 67-72.

Passam, H. C., Karapanos, I. C., Bebeli, P. J. and Savva, D. (2007). A review of recent research on tomato nutrition, breeding and post-harvest technology with reference to fruit quality. The European J. Pl. Sci. Biotechnol., 1(1): $1-21$.

Pratap, D., Kumar, S., Snehi, S. K. and Raj, S. K. (2012). Biological and Molecular characterization of Cucumber mosaic virus Isolate causing shoestring disease of Tomato in India which has Closer Affinity to European or East Asian Isolates of CMV. Indian J. Virol., 23(1): 57-63.

Roossinck, M. J., Zhang, L. and Hellwald, K. H. (1999). Rearrangements in the 50 non-translated region and phylogenetic analyses of Cucumber mosaic virus RNA3 indicate radial evolution of three subgroups. J. Virol. 73: 6752-6758.

Shahanavaj, K, Arif, T. J., Bushra, A., Quazi, M. and Rizwanul, H. (2011). Coat protein gene based characterization of Cucumber mosaic virus isolates infecting banana in India. J. Phytol., 3(2): 94-101.

Tamura, K., Stecher, G., Peterson, D., Filipski, A. and Sudhir, K., 2013, MEGA-A6: Molecular genetics analysis version software 6.06. Mol. Biol. Evol., 30(12): 2725-2729.

\section{How to cite this article:}

Gurudevi, V. Navali, S. Basavaraj, K.T. Rangaswamy and Prameela, H.A. 2018. Molecular Characterization of RNA3 of CMV Infecting Tomato from Karnataka, India. Int.J.Curr.Microbiol.App.Sci. 7(05): 805-811. doi: https://doi.org/10.20546/ijcmas.2018.705.098 